\title{
Perspective
}

\section{Striving for the United Nations (UN) Sustainable Development Goals (SDGs): what will it take?}

\author{
Anurag Saxena ${ }^{1} \mathbb{D} \cdot$ Meghna Ramaswamy $^{1} \cdot$ Jon Beale $^{2} \cdot$ Darcy Marciniuk $^{1} \cdot$ Preston Smith $^{1}$
}

Received: 10 February 2021 / Accepted: 23 March 2021

(C) The Author(s) 2021 OPEN

\begin{abstract}
The United Nations Sustainable Development Goals (UN SDGs) aim to develop healthy societies aligned with collective well-being. Although commendable efforts have been made, there has been a paucity of coordination and integration across sectors. While progress towards these goals has made a marked difference in peoples' lives, it has been slow, episodic, and geographically isolated. This article dissects the challenges and opportunities and addresses the interplay between conceptualization, implementation, and evaluation. We suggest that philosophic, strategic, and operational alignment between and strategic attention to transformative learning for education and organizational learning, leadership (that involves moral courage, judicious use of power and narratives, creating a sense of belonging, and adopting an integrated and dialectic approach) and robust partnerships across public, private and plural (civil society) sectors would increase the likelihood of success and sustainability beyond 2030. A dialectic approach integrating outcomes with SDGs' inspirational nature to guide the discourse would allow for emergence.
\end{abstract}

\section{Introduction}

The United Nations (UN) 2030 Agenda for Sustainable Development developed in 2015 represents an ambitious global framework. It redirects humanity towards a sustainable path to end poverty, hunger, inequality, and climate degradation, enable improved access to education and healthcare, and build just, peaceful, and equitable societies [1, 2]. The Sustainable Development Goals (SDGs) are relevant to all of us and require concerted action from multiple sectors (governments, businesses, and civil society) and ownership by every human being to achieve the 2030 Agenda [3, 4].

Some progress has been made in moving the agenda. It is well known and documented that globally many organizations are increasing their efforts to help achieve these goals [5-8]. The SDGs related to economic growth, sustainable industrialization, innovation, and sustainable production have attracted attention and investment from several major industries $[9,10]$. Higher education institutions (HEls), including universities, are now beginning to define learning objectives and content, introduce pedagogies to empower learners, and include sustainability policies and strategies into their management structures [11]. Increasingly, incentives and reward opportunities are now being introduced to academics to perform interdisciplinary research to solve sustainability problems using a moral compass [12-14]. Many countries have included SDGs in their national policies, e.g. Bhutan, Brazil, Cambodia, Colombia, Ethiopia, Finland, India, Indonesia, Mexico, Mozambique, Nepal, Philippines, Rwanda, and Switzerland [15]. The collaboration between IBM and civil society organizations to innovatively address plastic (re)usage is an example of leadership and cross-sectoral partnerships [16].

Anurag Saxena, anurag.saxena@usask.ca| 'College of Medicine, University of Saskatchewan, Rm 3A10, Health Sciences Bldg, 107 Wiggins Road, Saskatoon, SK S7N 5E5, Canada. ${ }^{2}$ Sustainable Development Solutions Network (SDSN) Canada, Faculty of Environment, University of Waterloo, Waterloo, ON, Canada. 
However, the emerging literature on the global indicators stresses that progress has been made only in some areas and in some countries [17]. The most recent 2019 report from the UN Secretary-General and the UN Department of Economic and Social Affairs [18] highlights that progress has been slow, uneven, and, in some instances, reversed, suggesting that the global goals are unlikely to be achievable by 2030 . This variation in progress can be partially attributed to different choices by countries in determining SDGs more relevant to their development. In 2019, diplomats and government leaders from the various UN Member States gathered at the UN High-Level Political Forum (HLPF) to review SDGs' progress and implementation [19]. During this summit, the UN Secretary-General's key message was that "the shift in development pathways to generate the transformation required to meet the SDGs by 2030 is not yet advancing at the speed or scale required" [20]. Interestingly, the paucity of representation from the Heads of several Member States at this meeting could suggest insufficient ambition and a lack of action-oriented commitment by the countries to accelerate the 2030 Agenda. Recently, the importance of barriers to and the implications of not achieving the SDGs was highlighted [21], imploring concerted action-oriented efforts. However, optimism that these goals can be achieved continues; besides, the UNSDGs do have an aspirational and inspirational value that helps shape the dialogue and global discourse.

This article aims to highlight the challenges associated with the implementation of the 2030 Agenda and suggest strategic attention to three areas to coherently move forward.

\section{Challenges}

It is helpful to understand what has contributed to the current state to inform the work ahead. Significant efforts to implement the SDGs into practice have faced many challenges (Fig. 1). These span the entire range from conceptualization (inherent conflicts in the framework and commitment) through implementation (prioritization, operationalization, policy coherence, collaboration, and resource deployment) to evaluation (exact measures and paucity of timely data). These are discussed below.
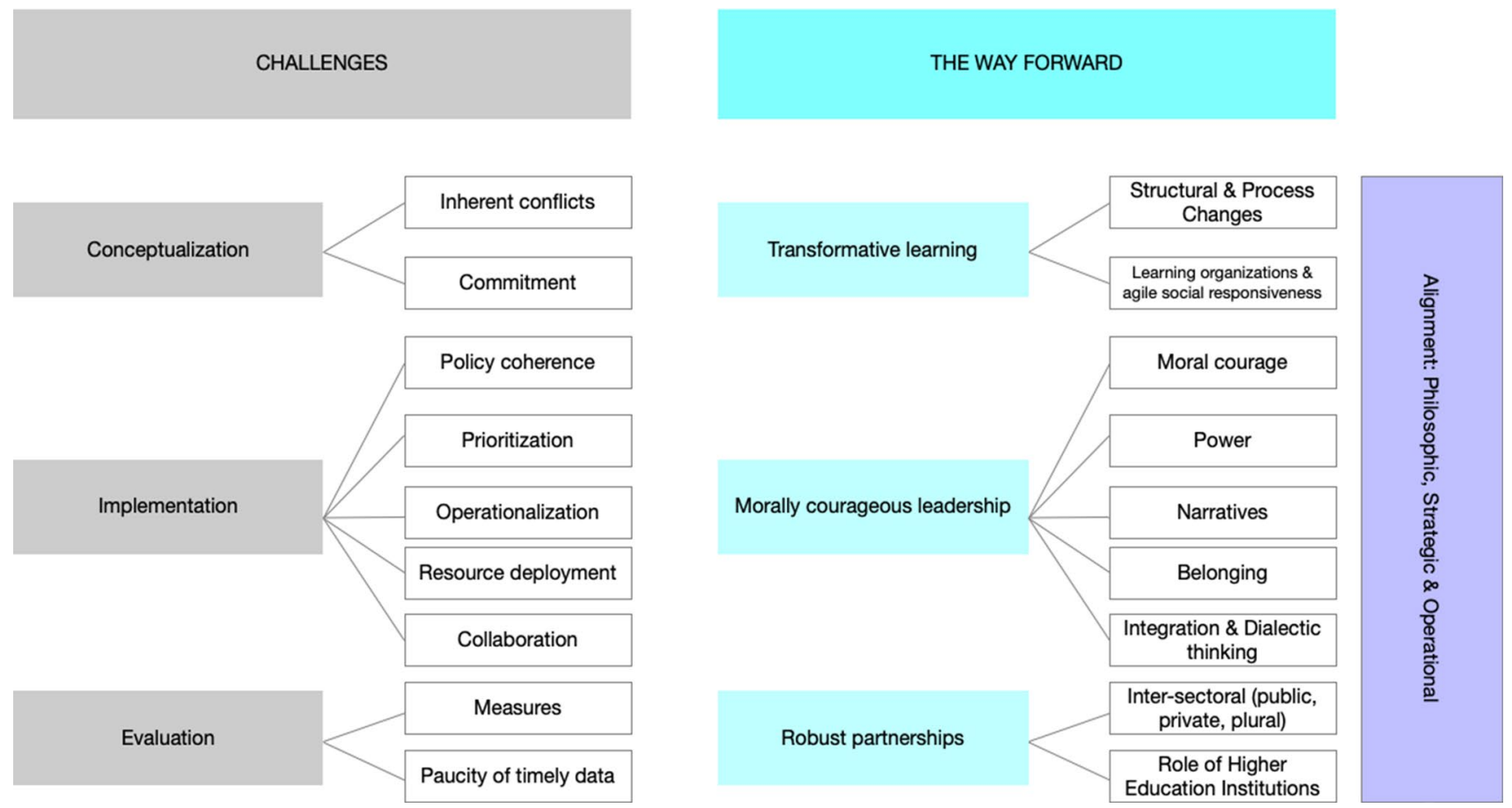

Fig. 1 Challenges and areas requiring strategic attention to achieve UNSDGs. The figure was made using Omnigraffle software and exported to TIFF format 


\subsection{Conceptualization}

The SDGs have been the subject of many critiques ranging from frank criticism through cautious support to optimism. Criticisms include a need for being more meaningful and accountable [22-24], do not account for restrictive forces and have only limited obligations to various stakeholders [25] with unrealistic timelines [26] and questionable diplomacy [23], the non-binding nature of the goals and targets, the realization of the goals considering the timeline, and the ambiguous nature of the financial investment for the goals. There is also the view that SDGs are neoteric and encyclopedic, "where everything is top priority, which means nothing is a priority" [24]. Interestingly, many studies have shown that economic growth can lead to the scarcity of natural resources, thus destroying our environment [27-29]. One could reasonably contend that the SDGs' conceptual framework reflects the intrinsic conflict between humanity and the planet [30-32].

Cautious support calls for enhancing integration across the SDGs and being more deliberate about "corporations," intergenerational equity, and international law [33], a need for re-evaluation in the current context to make these more viable [34], at risk for "sliding back" [35] and a need for change in strategy to achieve the goals [36, 37] and a systems approach. Since the SDGs' operationalization requires shared action and responsibility involving leaders from all sectors, the definition, and role of alliances between private, plural, and public sectors need further clarification. We use the term plural sector for civil society coined by Mintzberg as the term may be more representative of the groups and associations, and movements with varied representation and ownership [38]. The critique of SDGs also includes optimism as these are considered inspirational and achievable and make meaningful differences to underrepresented and marginalized citizens $[2,16,39]$.

\subsection{Implementation}

Localizing the SDGs nationally poses many challenges. With a rise in nationalism and a growing political divide between left and right, governments may prioritize local specific issues facing their country and their geographic regions [40-42]. Furthermore, political crises, corruption, and distrust of interventionist governments may result in outspoken opposition to active planning and roll-out of transformative actions required to realize the 2030 Agenda [43]. This state of affairs poses potential challenges in realizing global political agreements jointly on the SDGs and thus adversely impacts policy governance and coherence [1]. In contrast, a recent report indicated that the SDG framework provided smaller countries with an opportunity for expression, thus de-politicizing negotiations and avoiding entrenched North-South divides [44]. Social and environmental challenges pose a risk to achieving SDG 7 (Affordable and Clean Energy) and energy justice for developing countries [45]. Achieving a systemic change across the globe in a cross-cutting manner among actors and sectors that do not usually work together and can choose to focus on different SDGs is an ongoing challenge. Resources, especially financing, have been a significant hurdle. An approximate $\$ 2.5$ trillion annual financing gap identified early on [46] is continuing and has been a major impediment in progress [47]; furthermore, the Bertelsmann Stiftung report found that the global community does not invest enough in implementing the 2030 Agenda $[18,48]$.

\subsection{Evaluation}

The path to monitor and quantify the SDGs poses many challenges due to limited data availability. The absence of meaningful data remains a significant challenge for monitoring and evaluating SDGs' progress. For example, for ethnic minority, indigenous populations, and disabled persons, only fragmented data is presented [39]. Using the Driving Forces Pressures Impacts Responses methodology, economists [25] show that the inherent contradictions focus on state and impact, non-recognition of pressures and support for counterproductive drivers; this coupled with limited obligations to the public and private sector and weak agency acts as barriers to SDG implementation. A 2017 study [49] showed that there are inconsistencies in SDGs for simultaneous progression of environmental, economic, and social sustainability. These cause concern as the SDGs are non-binding and are prioritized differently in developed and developing countries [39].

\section{Challenges reframed as opportunities: from disparity to dignity}

The universal and global 2030 Agenda requires a human rights-centered perspective due to SDGs' universal, transformative, comprehensive, and inclusive nature [50] to "leave no one behind." SDG 10, in particular, commits to ensuring equality both within and between countries paying attention to marginalized and disadvantaged populations. Nevertheless, of the ten targets and 11 indicators, none commit countries to decrease the uneven distribution and widening of the wealth and 
income gap between populations and countries [51-53]. Several reports indicate that although SDG 10 represents a unique opportunity to narrow down on inequality, the language in the goals and targets are poorly aligned, thus jeopardizing its implementation [52].

The disparity may be evident in income equality, gender, disadvantaged, disabled, and marginalized populations. Urgent, coordinated action is required at all levels to tackle factors fuelling financial inequality and global economic governance by incorporating a global human-rights lens [54]. The lack of robust accountability systems [55] and monitoring of SDG 10 is a significant issue. The HLPF on Sustainable Development can play an essential role in monitoring the transnational dimensions of the SDGs through the Voluntary National Reviews (VNRs) and analyze the shortfalls of the current indicators proposed to measure progress towards SDG 10. Businesses are vital drivers of economic growth and can level the workforce's playing field by complying with policies to reduce biases and discrimination. SDG 10 closely links with SDG 5 on Gender Equality and supports SDG 8 on Decent Work and Economic Growth by increasing diversity of thought. This linkage would help create more stable and peaceful economies in line with SDG 16 by abating social tensions, which in turn may tackle problems associated with SDG 2 Zero Hunger, SDG 3 Health and Well-Being, and SDG 4 Education [56, 57]. According to the Director of Open and International Programmes at the Cambridge Institute for Sustainability and Leadership, it would be harder to secure public support for SDG 13 Climate Action targets on decarbonization if people are struggling with poverty and discrimination [57].

\section{Looking ahead (integrating concepts, implementation, and evaluation)}

Global actions take time, do not provide insights into a local context, and thus may be challenging to implement and be effective. Focusing on the SDGs'local and regional implementation indirectly influences the SDGs globally as all spheres of life are interconnected. Understanding the SDG framework and identifying its inconsistencies can help stakeholders prioritize the goals based on their interconnectedness and develop tools leading to improvements. Setting ambitious future goals to compensate for insufficient efforts in the present is a concept well understood in policymaking [37]. What is required is monitoring progress one step at a time as it allows for continuous and dynamic learning.

The key issues that need to be addressed are collaborative governance, combined use of deliberate and emergent strategy, system-wide allocation of resources (including financial resources), evaluation, and agile responsiveness. Creating an enabling environment for multiple stakeholders to promote and develop new forms of cooperative governance is essential, particularly for financial governance structure(s) to mobilize and utilize resources [58] as both capital (from regional and foreign sources) and better disclosure of relevant information is required. Capacity building and empowering people to make practical contributions in the face of limited competencies can promote healthy democracy and good governance. Research in related areas such as accounting [59] has an enabling role. Although the successful implementation of the 2030 Agenda relies heavily on financing, bridging the gap between knowledge and implementation requires reliable high-quality data. These aspects are especially challenging in developing countries as reliable and robust data systems require significant financial, human, and technical resources. Efforts to collect disaggregate country-level data for the SDGs will require developing nations to form partnerships and data mapping tools with the private sector, NGOs, and think tanks to address these hurdles.

Complexity science perspectives help UNSDGs as the work involves multiple nested and overlapping complex adaptive systems (CAS). CASs are living, non-linear, entangled, self-organizing, robust, and emergent; they rely on activities and interconnections (relationships) with multiple feedback loops between diverse constituent elements [60-62]. Three additional attributes are that the magnitude and scope of the input are not directly proportional to the output [63], the history of the CAS, although not deterministic, is relevant to the future [64], and the future is somewhat unknowable and unpredictable (but not random and may be patterned and lie within boundaries) [65]. The planet, regions, societies, sectors, organizations are CASs. These attributes inform the work in CASs, in contrast to cause-effect linear aspects of classic Newtonian models. Prioritization is essential; however, large system transformation requires multiple interventions moving ahead simultaneously $[66,67]$.

\section{The way forward}

The efforts to strive for SDGs would benefit from careful, coordinated strategic attention to three areas - transformative learning, meaningful and effective leadership, and robust partnerships within and across the three sectors (private, public and plural), which are aligned (philosophically, strategically, and operationally). 


\subsection{Transformative Learning (TL)}

Mindset refers to one's attitudes and predispositions to behavior and can either enable or impede behavior and action. It is one reason for slower progress towards achieving UNSDGs; a change towards a more learning orientation [68] and a better alignment with current and future needs have been proposed to ensure progress [69]. However, we posit that to strive for SDGs, a change is also needed in the mental models (syn. "frame of reference") that refer to one's cognitive representations of reality to assign meaning and influence behavior [70]. This change in the "frame of reference" can be achieved through Transformative Learning (TL). TL is defined as permanently changing one's frame of reference to be more expansive and inclusive by making meaning of experiences that are critical, ambiguous, and ill-structured [71]. By transcending boundaries between philosophy (e.g. the nature of being) and science, TL constructs a tangible bridge supported by three pillars of knowing-(i) instrumental (knowing that), (ii) communicative (knowing how), and (iii) emancipatory (knowing why) [72].

This learning will have the most impact if it is realized from micro to macro levels (individual, groups, community, nations, sectors, and global conglomerations). Ownership of the SDGs through individual choices and daily activities contributes to transforming oneself and the wider environment. The world is rife with examples of disorienting dilemmas such as the social, economic, and human rights crises of varying magnitudes. These can be utilized for a voluntary commencement of a TL journey through reflection on content, process and premise, and rational (related to thinking) and extra-rational discourse (based upon feelings and intuition) [72].

We discuss two aspects of TL directly relevant to achieving UN SDGs; first, the role of HEls in education and research, and secondly, the importance of insights gained through TL for organizations to inform, develop, and modify policies, strategies, processes, and tailored approaches to desired changes.

\subsubsection{TL and HEls}

The HEls have the opportunity to leverage TL in both education and research. In contrast to informative and formative learning, the former being concerned with information and skills leading to expertise and the latter being concerned with values and socialization leading to professionals, TL's objective is leadership attributes leading to the development of change agents [73]. Education for sustainability aimed at developing social change agents in a complex world requires the integration of diverse perspectives through strategies that promote reflection, dialogue, and individual growth in a supportive learning environment. The shift from market-oriented approaches to education for healthy integrated societies implores the HEls to simultaneously uphold and manage the polarities inherent in providing learner support (but not overly protective and stunt their development) [74] and create opportunities for transformation by guiding their TL journey that involves disorientation and reflection [75]. To become centres or catalysts of TL and cubicles of innovation, the HEls would need structures (supportive environments across diverse learning settings, faculty trained to co-create and evolve) and processes (meaningful curricular changes, and opportunities for reflection, dialogue, and discourse). This change is possible through an optimized integration of $T L$ in education for sustainability through collaborative learning spaces [76] and by including additional dimensions of structures, conflict, and social processes [77].

TL can also inform knowledge generation through research. It has been argued that the conventional incremental knowledge generation practices will reinforce the status quo and unsustainable practices, and a shift to generating practical wisdom (phronesis) "to inform judgment on sustainable development issues" is required [78]. In addition to empirical-analytic approach, this would entail a participatory process involving the stakeholders and an interpretive approach that enables and not just informs action. Patient-oriented research, that involves patients at all stages of the study, is one example. Partnering with healthcare managers and policymakers to conduct research for "interpretive synthesis" [79] is another example. To address bias in the publication process, a relatively new approach to research publication is "registered report," where articles are provisionally accepted after peer review of the hypotheses and analysis and before the study is entirely conducted [80]. 


\subsubsection{TL and organizational change}

Appropriate utilization of TL may lead institutions in all three sectors to become learning organizations and undergo transformation themselves, thereby making them socially responsive through education, research, and activities for social justice. For example, integrating public discourse and debates, evidence, and innovative instruments such as precautionary principle to existing political and market arenas are likely to improve decision-making [81] in these complex intertwined goals. The HEls would become relevant to society and resonate with the general public. Universities continue to be the most influential voice in the plural sector. Re(claiming) or enhancing the original purpose of education requires nurturing discourse and dialogue on different perspectives and ideologies, rather than succumbing to one thought and opinion, which is perceived to be more relevant at a specific time period. The success of TL in striving for SDGs is likely to manifest as widespread empowerment, constructive social action, addressing oppression, and critique of ideology [82].

\subsection{Leadership implications}

Leadership is a social construct and reflects contemporary thought. Both formal and informal leadership are critical for attaining SDGs. It is well understood that leadership is integral to a collective endeavor's success [83]. There are multiple perspectives on leaders and leadership with coexistence (to a variable degree) of classical, modernist, and postmodern perspectives to leadership practice in the organizations; however, the importance of contexts and relationships to be adaptive remains central. Leadership work will need to contextually and culturally integrate these perspectives and evolve, as one perspective is unlikely to be productive across space and time. Compared to the extensive literature on individual, team, and organizational leadership, research on cross-sectoral $[84,85]$ and global leadership [85-87] is limited. Delivering on the SDGs requires transformational and inclusive leadership at a global, national, and local level [88]. Transformational leadership is focused on the others' personal development by helping them reach higher levels of motivation and morality [89], and inclusive leadership refers to the promotion of diversity, improvement of peoples' ability to innovate and cope with uncertainty [90]. Also, humanistic leadership, which refers to leadership based on individual dignity and well-being, fundamental values, and common good to enhance meaning and purpose of human experience [91], is considered essential for acting collectively, reflectively, and deliberately towards sustainability [92]. We propose that leadership for sustainability requires attention to five key areas. These include exercising moral courage, utilizing power appropriately for the common good, leveraging narratives, enhancing a sense of belonging, and thinking about controversies and different perspectives through integration and a dialectic approach.

\subsubsection{Moral courage}

Moral courage refers to a readiness to endure danger for the sake of principle and act on moral convictions [93] despite the fear of social and economic consequences [94]. It is based on the premise that moral courage is a critical human attribute and not a supernumerary virtue. Leaders as individuals need to make the right choices and decisions in all situations concerning others in a collective enterprise. Moral authority and a clear understanding of benefits and risks associated with sustainability have been shown to enable transformation [95]. Diversity needs to be embraced at all levels. Research has shown social and environmental sustainability and profitability increase when boards have representation by women [96]. Innovative leadership and sound governance models involving multiple stakeholders are conducive to integrating sustainability.

\subsubsection{Power}

The UN 2030 Agenda calls for influential leaders in multiple sectors to shape global development, which has contributed to emphasizing power in certain aspects and marginalizing others [97, 98]. Leaders are likely to use both power and influence in steering towards the attainment of SDGs as these are useful in achieving organizational outcomes [99, 100]. Power may be considered the ability to achieve something in the face of resistance, and influence may be considered as the ability to achieve something in the absence of reprisal [101, 102]. Appropriate and judicious use of power without 
succumbing to its abuse would require the leaders to draw from at least three conceptualizations of power, including the structuralist (power-over; French and Raven's framework) [103], feminist (power-with and power-to; Allen's framework) [104] and the post-structuralist (power constituted through knowledge; Foucault's' framework) [105].

\subsubsection{Narratives}

Discourses and narratives are paramount as these are used to marginalize and normalize societies [105]. Narratives have both negative and positive impacts and help to explain the process of internalization in organizations. Whether these narratives come into play through what is encouraged or discouraged on campuses or through legislation by governments-which behind closed doors may succumb to lobbying by powerful corporations and special interest groups or what and how the media portrays the issues have considerable impact on public perceptions and consequent actions. What is required for the SDGs is a narrative about nuanced knowledge to create hope and motivation for a more informed and sustainable world. The transformational power of knowledge needs to be harnessed in a pluralist-participatory discourse in order for the SDGs to be successfully achieved [106]. The Visualize 2030 platform developed in collaboration with the UN Foundation and the World Bank encourages individuals to tell a data-driven story of how SDGs interact with each other and what actions might be required to achieve the SDGs by 2030 [107].

\subsubsection{Belonging}

A sense of belonging needs to be ignited through increased social connectedness and decreased isolation to promote peace and prosperity across cultures. Many studies have shown social connectedness contributes positively towards health and well-being, and financial and physical safety and security [108-110], while stigmatization is associated with uncertainty regarding belonging [111]. Connectedness can be viewed as a craving to be accepted in a community or a wider society. Achieving the SDGs requires organizations to cultivate a sense of belonging and inclusivity and empower their employees [112]. Social belonging has been linked to organizational commitment and engagement, and it can be proactively developed by utilizing gaining perspectives, encouraging mentorship, and finding empowerment [113].

\subsubsection{Integration and dialectic thinking}

The SDG framework requires critical thinking to contend with power structures [114]. Given the inherent conflict between some SDGs (economic development and climate change), especially when viewed with the lenses of short-term gains and geographic priorities, there is an apparent need to reconcile. Achieving meaningful assimilation of the people, planet, prosperity, peace, and partnership (5Ps) [115] requires stepping back to consider the broader potential of integration (collaborative group interactions where all stakeholders have a place in the solution) rather than compromising or win/ lose [116] and dialectic thinking (simultaneously upholding two or more perspectives/truths) [117-119]. An approach that addresses "trade-offs and overlaps" [120] and which is systems-based and integrated across diverse but interlinked facets of social, economic, and ecologic aspects has been put forward to sustain the efforts beyond 2030 [33, 121]. The inherent conflict and incompatibility between some SDGs, e.g. environmental sustainability and socio-economic growth, can be overcome by strategies such as investments in health programs and renewable energy [49]. Improved evaluation to determine the current status accurately, trajectories and gaps is required at multiple levels [44]; specific methodologies for countries have been proposed [122], as well as a need for better metrics that would account for "spillover effects" of the countries on the planet [123]. The coherence of democratic governance with economic, education, and geographic variables have been linked to progress [124] and integration of sustainable development in an organization's framework of business, strategy, and decision-making [125] and are likely to help achieve the SDGs.

\subsection{Mutually valued robust partnerships within and across all three sectors}

The centrality of collaborations across multiple stakeholders to achieve the SDGs is recognized through SDG 17, which calls for partnerships between and across the three sectors. In today's evolving landscape, development challenges are increasingly complex, persistent, and interlinked. These necessitate individuals from all sectors to work together to ensure effective use of resources by capitalizing on the comparative advantage of sharing resources, knowledge, and technology from each stakeholder and sector. 


\subsubsection{The public sector}

In the public sector, several countries (e.g. Finland, Sierra Leone, and Madagascar-not a comprehensive list) have addressed this issue by creating cross-ministerial committees to ensure the SDGs are included at the implementation level. Experts also indicate the importance of having a national monitoring framework to demonstrate stakeholder engagement in development cooperation $[126,127]$. Policymakers and development partners need to build on the present momentum while addressing current and emerging risks. Simultaneously, the lack of financial investment and allocation, lack of development and social cohesion, a potential increase in interest rates, and debt vulnerabilities could have adverse spillover effects. Building on initiatives to monitor progress cannot be understated and will be vital to unlocking the SDGs' full potential.

\subsubsection{The private sector}

There are four discourses (pro-, skeptical, middle-ground, and anti-private sector) on the private sector's role in SDGs that emphasize socio-economic development over environmental goals [128]. The private sector efforts solely through the Corporate Social Responsibility (CSR) lens and consequent actions, by themselves, are likely to be insufficient on their own [129]. However, the private sector has a compelling role to play in the realization of SDG 17 Partnerships for the Goals, as they are essential partners to investment and job creation and can create stable and sustainable communities. They provide critical insight into issues facing companies in terms of investment and bankable projects. They more importantly can support reconciliation efforts in local communities by integrating small local businesses into their supply chains, thus contributing to SDG 11 Sustainable Cities and Communities. It is crucial to engage with business leaders to leverage their experiences [130] and knowledge brokering with implications for policy and research [131]. Another way for businesses to implement the SDGs would be by ensuring that a company's philosophies and investment mandates align with sustainable development projects in developing countries, which require innovation, infrastructure, and investment [132].

\subsubsection{The plural sector}

The plural sector's role needs to become more integrated to create an upswell in social action. The plural sector plays a critical role in supporting marginalized societies to voice their grievances or concerns. However, its fragmented nature makes coherence difficult; this coupled with lack of access to data and increasing professionalization of NGOs, possibly because of state and corporation funding, is likely to curb their creativity [38]. A more effective public sector is integral to achieving UN SDGs whether the actions are at the individual level or collectively at the community level. How will multiple plural sector efforts come together to create a groundswell? Mintzberg [38] outlines three actions to be undertaken by the plural sector - immediate reversals (of destructive practices, entitlements and dogmas, that underlie these practices), widespread regeneration (consolidating multiple initiatives aimed at improving lives, liberties, and environment), and consequential reforms (based on genuine collaborations across sectors and aimed at improved orderliness from institutions) to achieve a balance in the society [133]. Within the plural sector, universities serve a critical role in striving for UN SDGs.

\subsubsection{Cross-sectoral partnerships}

Strong partnerships across all three sectors are required to achieve the sustainable development agenda. The weakest link is the partnerships between the plural and the other two sectors. Interestingly and contrary to many studies, recent data indicate that the plural sector plays only a moderate role in the participatory space of the 2030 Agenda [134]. This is concerning as the plural sector's role in promoting democratic governance and people-centered development is well understood [135]. To ensure effective engagement of the plural sector in the implementation process, it is essential that their involvement is not merely informative and that they have formal roles and formal consultations with all sectors of society. This sector needs to include strong partnerships with the private and public sectors to be more effective and meaningful [38]. The plural sector needs to become robust, and it needs to be perceived as robust by the other two sectors, such that it is at the table where decisions are made. There must be an enabling environment for their participation through access to resources and information, fundamental freedom, and outreach $[135,136]$.

Additionally, businesses may also offer support to the plural sector on projects related to achieving social justice and lead to women empowerment and transformative programs in education. How do we effectively move words into 
action? One way to strengthen country-level partnerships with the private sector is to develop a framework where the UN plays the role of a "match-maker" role or "convener" for partnerships [137]. Indeed, a report from the Joint Inspection Unit has developed 12 recommendations spanning seven actions for partnerships with the private sector [138]. This action would ensure partnerships remain well aligned for achieving the SDGs.

\subsection{Discerning TL, leadership, and partnerships in a successful response to a complex social issue}

An example of addressing a complex social issue that reflects utilizing a biopsychosocial-ecologic approach to achieve the goals is Brazil's successful handling of the HIV crisis. The ensuing summary based on peer-reviewed [139-146] and grey literature [63] discerns the contextually-informed approach into the use of TL, courageous and effective leadership, and robust partnerships across the three sectors. The findings are depicted in Fig. 2.

\subsubsection{Transformative learning:}

Many underlying assumptions were challenged, such as developing countries should focus on prevention (rather than treatment) as the costs were too high, uneducated patients cannot manage their complicated drug regimens, and integrated national health systems are crucial for implementing solutions. The change in mindsets and worldviews across sectors (e.g. people willing to come for testing as they believed the treatment was available) and organizations (e.g. considering drug use as a public health rather than a criminal justice issue) led to policies and programs (e.g. needle exchange program) to embrace the Durban conference consensus of the entire spectrum of prevention, managing risk, treatment, and care. A solution-focused approach and innovation were utilized to identify what was required to achieve the target rather than blaming barriers and challenges for inaction. A fragmented healthcare system with highly variable access across population segments was consolidated and enhanced through NGOs' and community level organizations' involvement to reach all segments of society and provide the full range of care involving people with different expertise.

\subsubsection{Courageous and effective leadership:}

Utilizing multiple leadership perspectives adapted to local contexts was integral; both formal and informal effective leadership were evident in the call for democratization, concerted social action, and legal challenges by the NGOs. Moral courage was evident in the decision to provide universal access to free medicines, standing up to international

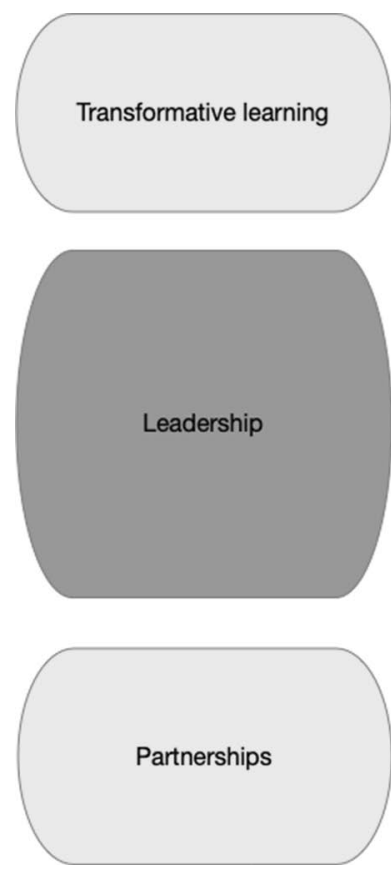

$$
\begin{aligned}
& \text { Interventions spanning prevention to treatment can be offered by developing countries despite high costs of medicines } \\
& \text { Changing the view of drug use from a criminal justice issue to a public health issue }
\end{aligned}
$$

Fragmented health care systems can be used in emergencies for effective care through plural sector partnerships

Morally courageous decisions: universal access to free medicines, standing up to international pressure and successfully negotiating loans and getting a motion adopted at the UN

Exercise of power by the government leverage a clause in WTO to produce generic drugs to serve the population and by the NGOs to mount legal challenges while developing collaborative relationships

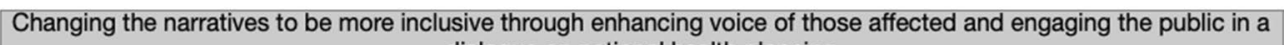
dialogue on national health planning

Collective belonging through concerted social action and coherence in actions amongst various stakeholders towards a common purpose

Integrated and dialectic approach to simultaneously provide resources for both prevention and treatment in a resource constrained environment

Public and private partnerships for production of generic medicines leading to a marked reduction in costs

Robust partnerships between public and plural sector to operationalize health care as a human right

Effective collaboration between the three sectors across the continuum of care (governments: surveillance and treatment; NGOs: promotion of human rights and infection prevention; private: timely production of generic drugs)

Fig. 2 Themes in Brazil's successful response to HIV crisis (extracted from references quoted in the text). The figure was made using Omnigraffle software and exported to TIFF format 
pressure, and successfully negotiating loans and a UN motion on treatment for AIDS as a human right [147]. The government's use of a clause in the WTO that permits a violation of patent laws in national emergencies and production of generic drugs with adequate funding [148] that reduced costs by $65-90 \%$ would be an example of the exercise of power for the greater good. Appropriate use of power was also observed in the social action (mounting legal challenges and creating coalitions) by the diverse plural sector. The public discourse (narratives) within the local context of wanting democratization (as opposed to military power) also changed due the affected people's voices and actions. The public was engaged in a structured debate about national health planning, and a collective sense of belonging was generated by actions and coherence of various stakeholders towards a common purpose. Integration and dialectic thinking were evident in the choice not to focus on either prevention or treatment but simultaneously. By providing hope, people came for testing and treatment, and these opportunities were used for education and knowledge dissemination for prevention.

\subsubsection{Partnerships:}

Brazil's success in handling the AIDS crisis rests upon effective collaboration across three sectors. The government's will in local and international actions, partnerships with both the local pharmaceutical companies and the plural sector (not just a nominal or consultative presence) has been referred to above. The plural sector's central role in mobilizing and galvanizing social action can be observed in such actions as developing AIDS NGO, sanitary reform movement, civil action lawsuits to human rights challenges, education, and being a catalyst of partnerships. These partnerships helped operationalize the constitutional right to health care as a fundamental human right and the government's responsibility. The plural sector's initiatives based on nondiscrimination and solidarity shaped the national program. Governments were responsible for surveillance and treatment, and the NGOs were responsible promoting human rights and preventing infection.

The national program(s) exhibited agile social responsiveness. The programs have been successfully sustained across multiple changes in the government over decades. However, a word of caution is necessary. As can be expected in any CAS, the gains require constant attention for sustainability, and the relatively recent rise in HIV positive cases in Brazil [149] requires renewed commitment and approaches. This brief non-comprehensive analysis highlights the importance of integrating the approaches, working across sectors, and an inclusive approach of treating people across divides and identities with respect and equity. However, historical and local contexts will remain critical in translating policy changes into active programs.

\section{Conclusion}

In conclusion, achieving the UN SDGs will require strong guiding leadership to develop strong partnerships across all three sectors and changing worldviews of citizens, corporations, governments, and institutions. Leadership styles and theories related to decision-making can be approached in two fundamental ways: Instrumental rationality (doing actions to achieve results) and Value rationality (commencing something as perceived to be of inherent value and taking the first steps are accomplishments by themselves). Even if some SDGs cannot be fully achieved by 2030 , working towards these is value-rational and a worthy exercise if we genuinely believe the goals are essential to sustainable development. A dialectic approach is required to balance concrete outcomes with the aspirational and inspirational nature to inform the narrative and allowing for emergence with some degree of uncertainty.

\footnotetext{
Authors' contributions All authors made substantial contributions to the intellectual content, approved the version to be published, and all agree to be accountable for all aspects of the work. The initial draft was developed (AS, MR) and revised by all authors. All authors read and approved the final manuscript.
}

Funding Self-funded.

Data availability Not applicable.

Declarations

Competing interests The authors declared no competing interests. 
Open Access This article is licensed under a Creative Commons Attribution 4.0 International License, which permits use, sharing, adaptation, distribution and reproduction in any medium or format, as long as you give appropriate credit to the original author(s) and the source, provide a link to the Creative Commons licence, and indicate if changes were made. The images or other third party material in this article are included in the article's Creative Commons licence, unless indicated otherwise in a credit line to the material. If material is not included in the article's Creative Commons licence and your intended use is not permitted by statutory regulation or exceeds the permitted use, you will need to obtain permission directly from the copyright holder. To view a copy of this licence, visit http://creativecommons.org/licenses/by/4.0/.

\section{References}

1. Bexell M, Jönsson K. Responsibility and the United Nations' sustainable development goals. Forum Dev Stud. 2017;44(1):13-29.

2. UN. Transforming our world: the 2020 Agenda for Sustainable Development A/RES/70/1. United Nations Sustainable Development Goals Knowledge Platform 201521 October 2015. https://sustainabledevelopment.un.org/post2015/transformingourworld/publication. Accessed 23 Mar 2020.

3. Corcoran PB, Weakland JP, Wals AE. Envisioning futures for environmental and sustainability education. Wageningen Academic Press: Wageningen; 2017.

4. Sachs JD, et al. Six transformations to achieve the sustainable development goals. Nat Sustain. 2019;2(9):805-14.

5. Grainger-Brown J, Malekpour S. Implementing the sustainable development goals: a review of strategic tools and frameworks available to organisations. Sustainability. 2019;11(5):1381.

6. Pedersen CS. The UN Sustainable Development Goals (SDGs) are a great gift to business! Procedia CIRP. 2018;69:21-4.

7. Rosati F, Faria LGD. Business contribution to the Sustainable Development Agenda: organizational factors related to early adoption of SDG reporting. Corp Soc Responsib Environ Manag. 2019;26(3):588-97.

8. WEF. World Economic Forum: From Funding to Financing Transforming SDG finance for country success. 2019. http://www3.weforum.org/ docs/WEF_From_Funding_to_Financing.pdf. Accessed 23 Mar 2020.

9. UN, United Nations Global Compact Progress Report 2019. 2019.

10. Agarwal, N., U. Gneiting, and R. Mhlanga, Raising the bar: Rethinking the role of business in the Sustainable Development Goals. 2017: Oxfam.

11. UNESCO. United Nations Educational, Scientific and Cultural Organization: Education for Sustainable Development Goals: Learning Objectives. 2017. https://unesdoc.unesco.org/ark:/48223/pf0000247444. Accessed 23 Mar 2020.

12. Howard, P., Who will teach the teachers? Reorienting teacher education for the values of sustainability. Teaching sustainability/teaching sustainably, 2012: 149-157.

13. Ramaswamy M, Marciniuk DD. Interdisciplinary Research Teams for the Sustainable Development Goals. In: LFW, et al. Eds. Partnerships for the Goals. Encyclopedia of the UN Sustainable Development Goals,. 2020, Springer: Cham.

14. Larrinaga-Gonzalez C. Sustainability reporting: insights from neo-institutional theory, in Sustainability Accounting and Accountability. London: Routledge; 2007.

15. OECD. Policy Coherence for Sustainable Development 2017: Eradicating Poverty and Promoting Prosperity. 2017. https://www.oecd-ilibrary. org/development/policy-coherence-for-sustainable-development-2017_9789264272576-en. . Accessed 23 Mar 2020.

16. UN. UN 2019 SDG Action Award winners. 2019. https://sdgactionawards.org/initiatives/1294/. Accessed 23 Mar 2020.

17. Salvia AL, et al. Assessing research trends related to Sustainable Development Goals: Local and global issues. J Clean Prod. 2019;208:841-9.

18. UN. The Sustainable Development Goals report 2019 from the United Nations Department of Social and Economic Affairs. 2019; https://unsta ts.un.org/sdgs/report/2019/The-Sustainable-Development-Goals-Report-2019.pdf

19. UN. Report of the high-level political forum on sustainable development convened under the auspices of the Economic and Social Council at its 2019 session. 2019. https://undocs.org/E/HLPF/2019/7. Accessed 23 Mar 2020.

20. IISD. UN Officials Highlight Findings of 2019 SDG Progress Report SDG Knowledge Hub 2019. Accessed 23 Mar 2020.

21. Leal Filho W, et al. Heading towards an unsustainable world: some of the implications of not achieving the SDGs. Disc Sustain. $2020 ; 1(1): 2$.

22. Fukuda-Parr S. Keeping out extreme inequality from the SDG Agenda-The Politics of Indicators. Global Pol. 2019;10:61-9.

23. Smith, J. and A. Gladstein. How the UN's Sustainable Development Goals undermine democracy. 2018. https://qz.com/africa/1299149/ how-the-uns-sustainable-development-goals-undermine-democracy/. Accessed 19 Oct 2020.

24. Easterly, W. The SDGs should stand for senseless, dreamy, garbled. 2015 March 23, 2020]; http://foreignpolicy.com/2015/09/28/the-sdgsare-utopian-and-worthless-mdg

25. Spangenberg JH. Hot air or comprehensive progress? A critical assessment of the SDGs. Sustain Dev. 2017;25(4):311-21.

26. Lieberman, A. SDGs show slow progress, not on track to reach 2030 targets, UN reports. 2018. https://www.devex.com/news/sdgs-showslow-progress-not-on-track-to-reach-2030-targets-un-reports-92971. Accessed 19 Oct 2020.

27. Repetto RC, et al. Wasting assets: natural resources in the national income accounts. DC: World Resources Institute Washington; 1989.

28. Pearce DW, Atkinson GD. Capital theory and the measurement of sustainable development: an indicator of "weak" sustainability. Ecol Econ. 1993;8(2):103-8.

29. Hamilton K, Clemens M. Genuine Savings Rates in Developing Countries. World Bank Econ Rev. 1999;13:333-56.

30. Redclift M. Sustainable development (1987-2005): an oxymoron comes of age. Sustain Dev. 2005;13(4):212-27.

31. Dasgupta P. The nature of economic development and the economic development of nature. Econ Pol Weekly. 2013;1:38-51.

32. Dasgupta PS, Ehrlich PR. Pervasive externalities at the population, consumption, and environment nexus. Science. 2013;340(6130):324-8.

33. Lim MM, Jørgensen PS, Wyborn CA. Reframing the sustainable development goals to achieve sustainable development in the anthropocene-A systems approach. Ecology and Society. 2018;23:3.

34. Editorial T. To revise the Sustainable Development Goals. Nature. 2020;583:331-2.

35. UN. SDG progress 'in danger' of going backwards without change in direction, new UN report reveals. 2019. https://news.un.org/en/ story/2019/09/1046132. Accessed 19 Oct 2020. 
36. Kuruvilla S, et al. The Global strategy for women's, children's and adolescents' health (2016-2030): a roadmap based on evidence and country experience. Bull World Health Organ. 2016;94(5):398.

37. Renn O. The Sustainable Development Goals could use a boost — and these five strategies might be just what's needed. Ensia 2019. https://www.minnpost.com/community-voices/2019/09/the-sustainable-development-goals-could-use-a-boost-and-these-five-strat egies-might-be-just-whats-needed/. Accessed 23 Mar 2020.

38. Mintzberg H. Time for the plural sector. Stanford Social Innovation Review 2015 Summer 2015 [cited 2020 March 23]; https://ssir.org/ articles/entry/time_for_the_plural_sector\#.

39. Swain RB. A critical analysis of the sustainable development goals. In: Handbook of sustainability science and research. Springer; 2018. p. 341-55.

40. Carius A, et al. A Foreign Policy Perspective on the SDGs. In: Climate Diplomacy. Germany: Berlin; 2018. p. 1-20.

41. Labonté R. Framing Political Change: Can a Left Populism Disrupt the Rise of the Reactionary Right?: Comment on "Politics, Power, Poverty and Global Health: Systems and Frames." Int J Health Policy Manag. 2017;6(9):547.

42. McArthur J, Muggah R. In an era of global uncertainty, the SDGs can be our guide. 2019. https://www.weforum.org/agenda/2019/03/inan-era-of-global-uncertainty-the-SDGs-can-be-our-guide/. Accessed 23 Mar 2020.

43. Randers J, et al. Transformation is Feasible-How to Achieve the Sustainable Development Goals Within Planetary Boundaries. A Report to the Club of Rome from Stockholm Resilience Centre and BI Norwegian Business School 2018. https://www.stockholmresilience.org/ publications/artiklar/2018-10-17-transformation-is-feasible---how-to-achieve-the-sustainable--development-goals-within-planetaryboundaries.html. Accessed 23 Mar 2020.

44. Fukuda-Parr S, McNeill D. Knowledge and Politics in Setting and Measuring the SDGs, Special Issue of Global Policy 2019. 2019.

45. Villavicencio CP, Mauger R. The UN's new sustainable development agenda and renewable energy: the challenge to reach SDG7 while achieving energy justice. J Energy Nat Resourc Law. 2018;36(2):233-54.

46. UNCTAD, Developing countries face $\$ 2.5$ trillion annual investment gap in key sustainable development sectors, UNCTAD report estimates. 2014, United Nations Conference on Trade and Development: Geneva, Switzerland.

47. Doumbia D, Lauridsen ML, Closing the SDG Financing Gap - Trends and Data. . International Finance Corporation. World Bank Group: Washingtons, DC; 2019.

48. Sachs J, et al. SDG Index and Dashboards Report 2018: Global Responsibilities, Implementing the Goals; Bertelsmann Stiftung and Sustainable Development Solutions Network (SDSN). 2018, Pica Publishing Ltd.: New York, NY, USA.

49. Spaiser V, et al. The sustainable development oxymoron: quantifying and modelling the incompatibility of sustainable development goals. Int J Sust Dev World. 2017;24(6):457-70.

50. OHCHR. Human rights and the 2030 agenda for sustainable development. https://www.ohchr.org/en/issues/SDGS/pages/the2030age nda.aspx. Accessed 07 Mar 2021.

51. Anderson E. Equality as a global goal. Ethics Int Aff. 2016;30(2):189-200.

52. Saiz I, Donald K. Tackling inequality through the Sustainable Development Goals: human rights in practice. Int J Human Rights. 2017;21(8):1029-49.

53. Donald K. SDG Targets risk missing the mark on inequality. Center for Economic and Social Rights 2016. http://www.cesr.org/sdg-targe ts-risk-missing-mark-inequality. Accessed 23 Mar 2020.

54. CESR. From Disparity to Dignity Tackling economic inequality through the Sustainable Development Goals. 2016 . https://www.cesr. org/sites/default/files/disparity_to_dignity_SDG10.pdf. Accessed 23 Mar 2020.

55. Ocampo JA, Gómez-Arteaga N. Accountability in International Governance and the 2030 Development Agenda. Global Pol. 2016;7(3):305-14.

56. ICSU. A Guide to SDG Interactions: from Science to Implementation. 2017. https://council.science/wp-content/uploads/2017/05/SDGsGuide-to-Interactions.pdf. Accessed 23 Mar 2020

57. Early C. SDG 10: Is tackling inequality the overlooked key to Sustainable Development? BusinessGreen 2019. https://www.businessgr een.com/feature/3080762/sdg10-is-tackling-inequality-the-overlooked-key-to-sustainable-development. Accessed 23 Mar 2020.

58. Weber O. The Financial Sector and the SDGs: Interconnections and Future Directions. 2018. https://www.cigionline.org/sites/default/ files/documents/Paper\%20No.201web.pdf. Accessed 23 Mar 2020.

59. Bebbington J, Unerman J. Achieving the United Nations sustainable development goals. Accounting: Auditing \& Accountability Journal; 2018.

60. Stacey RD. Complexity and Creativity in Organizations, ed Anonymous. San Francisco: Berrett-Koehler Publishers; 1996.

61. Cilliers P. Complexity \& Postmodernism, ed. Anonymous. New York: The Free Press; 1998.

62. Prigogine I, Stengers I. The end of certainty: time, chaos, and the new laws of nature, ed. Anonymous. 1997, New York: Published by Free Press by arrangement with Editions Odile Jacob.

63. Zimmerman BC, Lindberg P, PIsek P. Edgeware: Insights From Complexity Science For Health Care Leaders. 2nd ed. 2008, Irving, Texas: V H A, Incorporated.

64. Kauffman SA. At home in the universe: the search for laws of self-organization and complexity, ed. Anonymous. New York: Oxford University Press; 1995.

65. Stacey RD. Emerging Strategies for a Chaotic Environment. Long Range Plan. 1996;16:182.

66. Best A, et al. Large-system transformation in health care: a realist review. Milbank Q. 2012;90(3):421-56.

67. Beckhard R. Strategies for large system change. Sloan Manag Rev. 1975;16(2):43.

68. Phillips CA. We need a new mindset to advance the UN's Sustainable Development Goals and smart city initiatives. Sustainability 2020. https://17globalgoals.com/we-need-a-new-mindset-to-advance-the-uns-sustainable-development-goals-and-smart-city-initiatives/. Accessed 19 Oct 2020.

69. Farias $\mathrm{G}$, et al. Sustainability mindsets for strategic management: lifting the yoke of the neo-classical economic perspective. Sustainability. 2020;12:17.

70. Johnson-Laird PN. Mental models: Towards a cognitive science of language, inference and consciousness. Cambridge: Harvard University Press; 1983. 
71. Mezirow J. Understanding transformation theory. Adult Educ Q. 1994;44(4):222-32.

72. Saxena A. Transformative learning: premise, promise and challenges. Med Educ. 2019;53(6):534-6.

73. Frenk J, et al. Health professionals for a new century: transforming education to strengthen health systems in an interdependent world. Lancet. 2010;376(9756):1923-58.

74. Wilson R. An Epidemic of Anguish: Overwhelmed by demand for mental-health care, colleges face conflicts in choosing how to respond. The Chronicle of Higher Education, 2015.

75. Glisczinski DJ. Transformative higher education: a meaningful degree of understanding. J Transform Educ. 2007;5(4):317-28.

76. Schnitzler T. The bridge between education for sustainable development and transformative learning: towards new collaborative learning spaces. J Educ Sustain Dev. 2019;13(2):242-53.

77. Boström, M., et al., Conditions for Transformative Learning for Sustainable Development: A Theoretical Review and Approach. Sustainability, 2018. 10(12).

78. Loeber A. Designing for Phronèsis: Experiences with transformative learning on sustainable development. Crit Pol Stud. 2007;1 (4):389-414.

79. Lomas J. Using research to inform healthcare managers' and policy makers' questions: from summative to interpretive synthesis. Healthcare policy. 2005;1(1):55-71.

80. The Royal Society, Registered Reports: what are they and why they are important? 2016, The Royal Society.

81. Adetunji I, et al. The barriers and possible solution to achieve sustainable development. In: 2nd Scottish conference for Postgraduate Researchers of the Built and Natural Environment (PRoBE 2005). Glasgow, Great Britain: Conseil International du Bâtiment; 2005. p. 611-22.

82. Stuckey HL, Taylor EW, Cranton P. Developing a survey of transformative learning outcomes and processes based on theoretical principles. J Transform Educ. 2013;11(4):211-28.

83. Van Belle DA. Leadership and collective action: the case of revolution. Int Stud Quart. 1996;40(1):107-32.

84. Huxham C, Vangen C. Managing to collaborate: The theory and practice of collaborative advantage. New York: Routledge; 2005.

85. Crosby BC, Bryson JM. Leadership for the common good: tackling public problems in a shared-power world. San Francisco: Jossey-Bass; 2005.

86. Burns JM. Transforming leadership: the pursuit of happiness. New York: Atlantic Monthly Press; 2003.

87. Cleveland H. Nobody in charge: essays on the future of leadership. New York: John Wiley; 2002.

88. Bahauddin K. The Essence of Leadership for Achieving the Sustainable Development Goals. SDG Knowledge Hub 2018. https://sdg.iisd. org/commentary/generation-2030/the-essence-of-leadership-for-achieving-the-sustainable-development-goals/. Accessed 23 Mar 2020.

89. Bass BM, Avolio B, Improving organizational effectiveness through transformational leadership. . Thousand Oaks. CA: SAGE Publications; 1994. p. 238.

90. Bourke J. The six signature traits of inclusive leadership: Thriving in a diverse new world. 2016. https://www2.deloitte.com/us/en/insig hts/topics/talent/six-signature-traits-of-inclusive-leadership.html?id=us:2em:3na:dup3046:awa:dup:070816. Accessed 7 Mar 2020.

91. Lawrence PR, Pirson M. Economistic and humanistic narratives of leadership in the age of globality: toward a renewed darwinian theory of leadership. J Bus Ethics. 2015;128(2):383-94.

92. Kurucz EC, et al. Relational leadership for strategic sustainability: practices and capabilities to advance the design and assessment of sustainable business models. J Clean Prod. 2017;140:189-204.

93. Kidder RM. Moral courage, digital distrust: ethics in a troubled world. Bus Soc Rev. 2005;110(4):485-505.

94. Petersen C, Seligman M. Character strengths and virtues: a handbook and classification. New York: American Psychological Association and Oxford University Press; 2004.

95. Adams CA. The role of leadership and governance in transformational change towards sustainability. Global Responsibility. 2013;9:9-12.

96. McElhaney KA, Mobasseri S. Women create a sustainable future. Center for Responsible Business. 2012. https://www.eticanews.it/wpcontent/uploads/2012/11/Report-Women_Create_Sustainable_Value.pdf. Accessed 23 Mar 2020.

97. Adams B, Tobin K. Confronting development: a critical assessment of the UN's Sustainable Development Goals. 2014, New York: Rosa Luxemburg Stiftung, New York Office.

98. Esquivel V. Power and the sustainable development goals: a feminist analysis. Gend Dev. 2016;24(1):9-23.

99. Ahlquist JS, Levi M. Leadership: what it means, what it does, and what we want to know about it. Annu Rev Polit Sci. 2011;14:1-24.

100. McClelland DC, Burnham DH. Power is the great motivator. Harv Bus Rev. 2003;81(1):117-26.

101. Rashotte LS, Webster M Jr. Gender status beliefs. Soc Sci Res. 2005;34(3):618-33.

102. Dahl RA. The concept of power. Behav Sci. 1957;2(3):201-15.

103. Raven BH. The bases of power and the power/interaction model of interpersonal influence. Anal Soc Issues Public Policy. 2008;8(1):1-22.

104. Allen A. Rethinking power. Hypatia. 1998;13(1):21-40.

105. Foucault M, Gordon G. Power/knowledge: selected interviews and other writings. Harvester Press. Vol. 206. 1980, Brighton, Sussex. 381-93.

106. Cummings S, et al. Critical discourse analysis of perspectives on knowledge and the knowledge society within the Sustainable Development Goals. Dev Pol Rev. 2018;36(6):727-42.

107. Youth S. Visualize 2030 Data Storytelling Contest. 2018. https://sdsnyouth.org/my-data-blog/2018/11/8/visualize-2030-data-storytelli ng-contest. Accessed 2 Nov 2020.

108. Cattell V. Poor people, poor places, and poor health: the mediating role of social networks and social capital. Soc Sci Med. 2001;52(10):1501-16.

109. Kahneman D, Krueger AB. Developments in the measurement of subjective well-being. J Econ Persp. 2006;20(1):3-24.

110. Putnam RD. Bowling alone: The collapse and revival of American community. United States of America: Simon E Schuster Paperbacks; 2000. p. 19.

111. Walton GM, Cohen GL. A question of belonging: race, social fit, and achievement. J Pers Soc Psychol. 2007;92(1):82-96.

112. Baumeister RF, Leary MR. The need to belong: desire for interpersonal attachments as a fundamental human motivation. Psychol Bull. 1995;117(3):497. 
113. Carr E, et al. The Value of Belonging at Work. 2019. https://hbr.org/2019/12/the-value-of-belonging-at-work. Accessed 23 Mar 2020.

114. Boluk KA, Cavaliere CT, Higgins-Desbiolles F. A critical framework for interrogating the United Nations Sustainable Development Goals 2030 Agenda in tourism. J Sustain Tour. 2019;27(7):847-86.

115. Brown K, Rasmussen K. The sustainable development goals in 2019: People, planet, prosperity in focus. 2019, United Nations Foundation.

116. Follett MP. Constructive conflict, in Bureau of Personnel Administration 1925, Harvard Business School Press. p. 67-95.

117. Kioupi V, Voulvoulis N. Education for sustainable development: A systemic framework for connecting the SDGs to educational outcomes. Sustainability. 2019;11(21):6104.

118. Baxter LA, Scharp KM, et al. Dialectical Tensions in Relationships. In: Berger CR, et al., editors. The International Encyclopedia of Interpersonal Communication. New York: John Wiley \& Sons; 2015. p. 1-6.

119. Levine D. Simmel: on individuality and social forms. Chicago: University of Chicago Press; 1971.

120. Nilsson M, Griggs D, Visbeck M. Policy: map the interactions between sustainable development goals. Nature. 2016;534(7607):320-2.

121. Morton S, Pencheon D, Squires N. Sustainable Development Goals (SDGs), and their implementation: a national global framework for health, development and equity needs a systems approach at every level. Br Med Bull. 2017;124(1):81-90.

122. McArthur JW, Rasmussen K. Classifying Sustainable Development Goal trajectories: a country-level methodology for identifying which issues and people are getting left behind. World Dev. 2019;123:104608.

123. Schmidt=Traub G, Hoff H, Bernlöhr M. International spillovers and the sustainable development goals (SDGs): Measuring how a country's progress towards the SDGs is affected by actions in other countries, in SDSN Policy Brief. 2019. p. 1-16.

124. Glass L-M, Newig J. Governance for achieving the Sustainable Development Goals: How important are participation, policy coherence, reflexivity, adaptation and democratic institutions? Earth Syst Govern. 2019;2:100031.

125. Adams CA. The Sustainable Development Goals, integrated thinking and the integrated report. 2017.

126. Risse N. Getting up to speed to implement the SDGs: Facing the challenges. SDG knowledge hub policy brief 2017. http://sdg.iisd.org/ commentary/policy-briefs/getting-up-to-speed-to-implement-the-sdgs-facing-the-challenges/. Accessed 23 Mar 2020.

127. UNDESA. Overview of institutional arrangements for implementing the 2030 Agenda at national level. 2017. https://sustainabledeve lopment.un.org/content/documents/10735Updated_Issues_Brief_rev10_1_March_2017.pdf. Accessed 23 Mar 2020

128. Cummings S, Anastasia-Alithia S, de Haan L. Getting down to business? Critical discourse analysis of perspectives on the private sector in sustainable development. Sustain Dev. 2020;28(4):759-71.

129. Mintzberg H. Please Welcome CSR 2.0, in Rethinking Strategic Management. New York: Springer; 2019. p. 43-6.

130. Moreira da Silva J. Opinion: Yes, the private sector is good for development. The question is how. 2017.

131. Cummings S, Kiwanuka S, Regeer B. The private sector in knowledge brokering for international development: what the experts say. Inform Dev. 2020;1:0266666920977597.

132. PwC. SDG17: partnerships for the goals; Strengthen the means of implementation and revitalise Global Partnership for Sustainable Development. https://www.pwc.com/mu/en/events/CRA2019/cragoals/Goal17.pdf. Accessed 23 Mar 2020.

133. Mintzberg H, Rebalancing society. . Oakland. CA: Berrett-Koehler Publishers Inc; 2015.

134. Sénit C-A. Leaving no one behind? The influence of civil society participation on the Sustainable Development Goals. Environment and Planning C: Politics and Space; 2019. p. 2399654419884330.

135. Hassan MM, Lee KE, Mokhtar M. Mainstreaming, Institutionalizing and Translating Sustainable Development Goals into Non-governmental Organization's Programs. In: Concepts and Approaches for Sustainability Management. Cham: Springer; 2020 . p. 93-118.

136. Dattler R. Not Without Us: Civil Society's role in implementing the Sustainable Development Goals. 2016. http://www.euro.who.int/_ data/assets/pdf_file/0006/319308/6-Not-without-us-civil-society-role-implementing-SDGs.pdf?ua=1. Accessed 23 Mar 2020.

137. UNGC. Global Compact International Yearbook 2015. 2016. https://shop.un.org/books/global-compact-intl-yrbk-2015-49238. Accessed 23 Mar 2020.

138. Dumitriu P. The United Nations system - Private Sector partnerships arrangements in the context of the 2030 agenda for sustainable development. Geneva: Switzerland; 2017.

139. Berkman A, et al. A critical analysis of the Brazilian response to HIV/AIDS: lessons learned for controlling and mitigating the epidemic in developing countries. Am J Public Health. 2005;95(7):1162-72.

140. Nunn AS, et al. AIDS treatment in Brazil: impacts and challenges. Health Aff (Millwood). 2009;28(4):1103-13.

141. Greco DB, Simao M. Brazilian policy of universal access to AIDS treatment: sustainability challenges and perspectives. AIDS. 2007;21(Suppl 4):S37-45.

142. Urias $\mathrm{E}$. The potential synergies between industrial and health policies for access to medicines: insights from the Brazilian policy of universal access to HIV/AIDS treatment. Innov Dev. 2019;9(2):245-60.

143. Liamputtong P. Stigma, Discrimination and Living with HIV/AIDS. Dordrecht: Springer; 2013.

144. Galvão J. Brazil and access to HIV/AIDS drugs: a question of human rights and public health. Am J Public Health. 2005;95(7):1110-6.

145. Gomez EJ. The Politics of Brazil's Successful Response to HIV/AIDS: Civic Movements, Infiltration, and "Strategic Internationalization." Brown J World Affairs. 2011;17(2):51-64.

146. de la Rafael D. NGOs, Governmentality, and the Brazilian Response to AIDS: A Multistranded Genealogy of the Current Crisis. Fem Stud. 2017;43(2):262-90.

147. Mintzberg H, Azevedo G. Fostering "Why not?" social initiatives - beyond business and governments. Dev Pract. 2012;22(7):895-908.

148. Reuters, Brazil May Defy U.S. and Make More AIDS Drugs, in The New York Times. 2001: New York.

149. Grangeiro A, Castanheira ER, Nemes MIB. A re-emergência da epidemia de aids no Brasil: desafios e perspectivas para o seu enfrentamento. Interface - Comunicação, Saúde, Educação. 2015;19:5-8.

Publisher's Note Springer Nature remains neutral with regard to jurisdictional claims in published maps and institutional affiliations. 